\title{
Antibiogram of Bacteria Isolated from Kunun-Zaki Drink Sold in Keffi Metropolis
}

\author{
${ }^{1}$ Makwin Danladi Makut, ${ }^{2}$ Mary Azumi Nyam, \\ ${ }^{1}$ Smart Obumneme Obiekezie and ${ }^{1}$ Aisha Eleojo Abubakar \\ ${ }^{1}$ Department of Biological Sciences,
Faculty of Natural and Applied Sciences, Nasarawa State University, Keffi, Nigeria \\ ${ }^{2}$ Department of Plant Science and Technology, \\ Faculty of Natural Sciences, University of Jos, Jos, Nigeria
}

Received 2013-08-17, Revised 2013-09-04; Accepted 2013-09-06

\begin{abstract}
Kunun-zaki drink is a locally prepared indigenous non-alcoholic beverage that is widely produced and consumed in Nigeria. Standard microbiological methods were employed to isolate bacteria from Kunun-zaki drink sold in Keffi metropolis, Nasarawa State, Nigeria. Samples of Kunun-zaki drink were collected from ten (10) different locations and their bacteriological loads were determined in terms of total bacterial counts using standard methods involving pour plate. The antibiotic resistance pattern of the bacterial isolates against some antibiotics was determined using the Kirby-Bauer disk diffusion method. The bacterial counts of the Kunun-zaki in the ten different locations range from $9.1 \times 10^{8}$ to $2.6 \times 10^{8} \mathrm{cfu} / \mathrm{mL}$. Four species of bacteria were isolated and identified by standard microbiological methods and these were Escherichia coli, Enterobacter aerogenes, Staphylococcus aureus and Streptococcus spp. The most predominant isolate in terms of occurrence was Escherichia coli $(100 \%)$ followed by Enterobacter aerogenes (70\%), Staphylococcus areus (30\%) and Streptococcus spp (10\%). Escherichia coli showed high resistance to Chloramphenicol (75\%), followed by Septrin (68.7\%) and Sparfloxacin (68.7\%), while Enterobacter aerogenes, Streptococcus spp and Staphylococcus areus had low rates of resistance to all the antibiotics tested. E. coli had very sensitivity to Pefloxacin (100\%), Gentamicin (88\%), Amoxicillin (88\%), Augmentin (75\%), Tarivid (68.7\%) and Streptomycin (68.7\%). Streptococus spp are the most susceptible isolates which had $100 \%$ sensitivity to Septrin, Chloramphenicol, Amoxicillin, Gentamicin and Pefloxacin respectively and this was followed by Staphylococcus areus which had $100 \%$ sensitivity to Chloramphenicol, Amoxicillin, Augmentin and Tarivid respectively. The antibiotic resistance pattern exhibited by $E$. coli isolated from the Kunun-zaki sold in Keffi is indicative of possible abuse of the use of antibiotics and this has serious health implications. The results of this study demonstrate that Kunun-zaki sold in Keffi is contaminated with potentially pathogenic bacteria including antibiotic resistant E. coli and these may lead to failures in antibiotic chemotherapy among consumers of Kunun-zaki in the Keffi metropolis.
\end{abstract}

Keywords: Antibiogram, Antibiotics, Resistance, Kunun-Zaki, Keffi

\section{INTRODUCTION}

Kunun-Zaki drink is a locally prepared indigenous non-alcoholic beverage (Maji et al., 2011) which is widely produced and consumed in large quantity in Nigeria, especially the northern part of the country
(Amusa and Ashaye, 2009). This local beverage is consumed in both wet and dry season because of its optimal thirst quenching abilities.

Kunun-zaki drinks are usually produced using maize, guinea corn, millet or sorghum in in varying proportions (Maji et al., 2011) to which sweet potato is

Corresponding Author: Makwin Danladi Makut, Department of Biological Sciences, Faculty of Natural and Applied Sciences, Nasarawa State University, Keffi, Nigeria 
sometimes added so as to increase the tasteof the Kununzaki which is a major factor that attracts consumers to the product. The ingredients used are usually not quantified and are very unique because they are sourced locally. The methods involved in the production of this local beverage include steeping the grains in some containers such as buckets and some other household utensils (Maji et al., 2011; Oluwajoba et al., 2013) followed by grinding the steeped grains into a mash and then mixed up with some spices of choice such as pepper and ginger before it is then divided into two in equal proportions (Amusa and Ashaye, 2009; Oluwalana and Adedeji, 2013). One of the proportions is then mixed up with hot or boiled water and the other with some ingredients such as malted rice and sweet potato paste. The two proportions are then mixed together at at a temperature of about $75-80^{\circ} \mathrm{C}$ as the mixture is left to undergo fermentation at room temperature within 20-24 $\mathrm{h}$, after which it is sieved before being considered ready for consumption (Amusa and Ashaye, 2009; Akoma et al., 2013). Some individuals and communities prefer Kunun-zaki with much pepper and sugar (Amusa and Ashaye, 2009; Adedokun et al., 2012). This common drink is usually packaged and sold in $50 \mathrm{~mL}$ to 1 litre plastic bottles and at times tied in some disposable polythene bags. The drink is mostly consumed within 20-35 h of its production due to its poor keeping quality (Akoma et al., 2012). This drink is not expensive because the grains and other ingredients used for production are locally sourced and are mostly grown within the savannah region and almost throughout the years, most especially the savannah belt of West Africa. The packaging materials are also available, cheap and easily affordable. Kunun-zaki has been reported to be rich in vitamins, minerals, carbohydrates and proteins (Adebayo et al., 2010; Essien et al., 2009; Folasade and Oyenike, 2012; Oluwajoba et al., 2013). No elaborate equipment and expertise are required for its production (Akoma et al., 2013; Oluwalana and Adedeji, 2013). The water content coupled with the crude method of production and packaging that is under an improper sanitary conditions predisposes the drink to sudden microbial contamination (Akoma et al., 2012).

The ubiquitous nature of microorganism guarantees them the opportunity to be found in this locally made beverage drink and possibly in the water used for its preparation, during storage and other processes involved in its preparation. Some of the bacterial species that are associated with this locally produced beverage drink include spoilage species, pathogenic species, coliforms and lactic acid bacteria
(Amusa and Ashaye, 2009; Bukar et al., 2010; Akoma et al., 2012).

Kunun-zaki drink have been reported to have high nutritional value because of the raw materials from which it is made. Spices are usually added in small quantities to improve taste and flavour as these are agricultural commodities which may contain a high level of microbial impurities and these can be sources of contaminants, spoilage and pathogenic microorganisms (Essien et al., 2009).

Kunun-zaki is typically known as the locally made non-alcoholic fermented drink that has a high nutritional value because of the raw materials used in its production. As some spices are usually added in small quantities to improve their taste and flavor, being agricultural commodities, they will contain high level of microbial impurities, which can serve as a source of microorganisms (Lawal, 2012). Normally the $\mathrm{pH}$ values of Kunun-zaki are too low, a property which checks the growth of pathogenic microorganisms. The presence of bacteria such as Staphylococcus aureus, Escherichia coli and Streptococcus spp. could be a serious problem as Staphylococcus aureus is a normal flora of the skin, palms, nose, throat, mucus membrane and a common ecological agent of septic arthritis (Willey et al., 2008). Escherichia coli is an important member of the coliform group. It is a part of the normal flora of the human intestine and some vertebrates, even though strain of this organism can be pathogenic.

The presence of these pathogens even in small numbers could render a beverage unsuitable for human consumption (Amusa and Ashaye, 2009; Essien et al., 2009; Lawal, 2012). It is very possible that the contamination by these pathogens could have occurred, during hawking and packaging of the products due to improper or careless handling of the products leading to contamination of products. Food contamination by specific organisms is largely due to the presence of these organisms and their entrance into the food or beverage drinks as a result of poor hygiene and sanitation (Bukar et al., 2010). The predominance of Lactobaccillus fermentum and Lactobaccillus leichamani bring about heavy contamination and spoilage (Akoma et al., 2012).

The main components of cereals from Kunun-zakidrinks are carbohydrates, vitamins, minerals and proteins and the main products of fermentation is lactic acid and this leads to a decrease in $\mathrm{pH}$ values and an increase in acidity (Maji et al., 2011; Oluwalana and Adedeji, 2013).

This study is aimed at determining the antibiogram of bacteria present in Kunun-zaki drink sold in Keffi Metropolis, Nasarawa State, Nigeria. 


\section{MATERIALS AND METHODS}

\subsection{Study Area}

The study area is Keffi town, an ancient town in Nasarawa State located in the northern part of Nigeria. Keffi is about $58 \mathrm{~km}$ away from the Federal Capital Territory (FCT) Abuja and $129 \mathrm{~km}$ away from Lafia, the capital of Nasarawa state. Nasarawa State is located on latitude $8^{\circ} 32^{\prime} \mathrm{N}$ and longitude $8^{\circ} 32^{\prime} \mathrm{N}$ (Wikipedia, 2013).

\subsection{Sample Collection}

Ten different locations where Kunun-zaki sold in Keffi metropolis were randomtly selected for the purposes of sample collection. Samples of the Kunun-zaki were aseptically collected in triplicates in into sterile corked plastic tubes from from the ten different locations. The samples were labeled appropriately, placed into separate plastic bags and conveyed in an ice packed cooler to the Microbiology laboratory of the Nasarawa State University, Keffi. The ten different locations were samples were collected included Angwan Lambu, Angwan Tiv, Angwan Waje, Angwan Nepa, Area Commander, Convocation Square of Nasarawa State University, CRDP, Sohon Kasuwa, High Court and Locust.

\subsection{Determination of Aerobic Plate Count}

Standard Plate Count method was used to determine the Total Aerobic Colony count of the samples (Sanders, 2012). A seven-fold serial dilution of each sample was made and plated out on Aerobic Plate Agar using spread plate technique. The plates were incubated at $37^{\circ} \mathrm{C}$ for $24 \mathrm{~h}$. The average microbial loads of the Kunun-zaki samples obtained from the different locations were expressed as Colony Forming Units per milliliter (CFU/mL) of Kunun-zaki.

\subsection{Isolation and Identification of Bacteria Isolated from Samples}

McConkey agar, Chocolate agar, Eosin Methylene Blue, Manitol Salt agar and Salmonella-Shigella agar were employed for the isolation of bacteria for the purposes of identification. McConkey agar was used to isolate lactose fermenting gram negative bacteria, Chocolate agar was used to isolate fastidious bacteria, Eosin Methylene Blue was used for the selective isolation of enteric coliforms, Manitol Salt agar was for the selective isolation of salt-tolerant bactria and Salmonella-Shigella agar was used for the isolation of enteric bacilli particularly Salmonella and Shigella species. All plates were incubated at $37^{\circ} \mathrm{C}$ for $24 \mathrm{~h}$. Identification of bacterial isolates was based on the standard cultural, morphological and biochemical methods (Holt, 1994; Cheesbrough, 2006).

\subsection{Antibiotic Susceptibility Test}

The isolates were screened for antimicrobial susceptibility using the Kirby-Bauer agar disk diffusion method (CLSI, 2009). A suspension of each isolate was prepared in peptone water to match 0.5 McFarland turbidity standards in order to standardize the inoculum. The standardized inoculum of each isolate was inoculated in triplicates onto the surfaces of plain Mueller-Hinton agar plates and Septrin (30 $\mu \mathrm{g})$, Chloramphenicol $(30 \mu \mathrm{g})$, Sparfloxacin $(5 \mu \mathrm{g})$, Amoxycillin (30 $\mu \mathrm{g})$, Ciprofloxacin (5 $\mu \mathrm{g})$ Augmentin (30 $\mu \mathrm{g})$, Gentamicin $(10 \mu \mathrm{g})$, Pefloxacin $(10 \mu \mathrm{g})$, Tarivid $(30 \mu \mathrm{g})$ and Streptomycin $(10 \mu \mathrm{g})$ discs were placed and incubated at $37^{\circ} \mathrm{C}$ for $24 \mathrm{~h}$. The zones of inhibition were measured and compared with the Clinical and Laboratory Standards Institute (CLSI) guidelines (CLSI, 2009).

\subsection{Statistical Analyses}

The data obtained were analysed using Statistical Package for Social Sciences (SPSS) version 20.0 software (SPSS, 2012). The analyses involved computation of averages, proportions (percentages), One-way and Twoway analysis of variance as well as the test for Least Significant Difference to separate means.

\section{RESULTS}

Table 1 shows the total aerobic bacterial counts of Kunun-zaki sold at the different locations in Keffi metropolis. The counts range from was $9.1 \times 10^{8} \mathrm{cfu} / \mathrm{mL}$ (which was highest recorded in Sohon Kasuwa) and $3.6 \times 10^{8} \mathrm{cfu} / \mathrm{mL}$ (which was the lowest recocrded for High Court).

Table 1. Total bacterial counts (cfu/ml) of Kunun-zaki drinks sold

\begin{tabular}{ll}
\hline Location & Kunun-zaki \\
\hline A & $5.0 \times 10^{8}$ \\
B & $6.3 \times 10^{8}$ \\
C & $4.7 \times 10^{8}$ \\
D & $7.0 \times 10^{8}$ \\
E & $4.0 \times 10^{8}$ \\
F & $8.6 \times 10^{8}$ \\
G & $6.0 \times 10^{8}$ \\
H & $9.1 \times 10^{8}$ \\
I & $3.6 \times 10^{8}$ \\
J & $5.7 \times 10^{8}$ \\
\hline
\end{tabular}

Key: $\mathrm{A}=$ Angwan Lambu; $\mathrm{B}=$ Angwan Tiv; $\mathrm{C}=$ Angwan Waje; $\mathrm{D}=$ Angan Nepa $\mathrm{E}=$ Area Command; $\mathrm{F}=$ Convocation Square; $\mathrm{G}=\mathrm{CRDP} ; \mathrm{H}=$ Sohon Kasuwa I = High Court; $\mathrm{J}=$ Locust 
Table 2. Bacterial isolates from samples of Kunun-zaki sold in different locations

\begin{tabular}{llllllllllll}
\hline & \multicolumn{1}{l}{ Locations } & \multicolumn{1}{c}{} & & & & & & & & & \\
Bacterial isolates & A & B & C & D & E & F & G & H & I & J & Occurrence frequency (\%) \\
\hline Escherichia coli & + & + & + & + & + & + & + & + & + & + & 100 \\
Staphylococcus aureus & + & - & - & + & - & + & - & - & - & - & 30 \\
Streptococcus spp & - & - & - & - & + & - & - & - & - & - & 10 \\
Enterobacter aerogenes & + & + & + & - & + & + & + & - & - & + & 70 \\
\hline
\end{tabular}

Key: A = Angwan Lambu; $\mathrm{B}=$ Angwan Tiv; $\mathrm{C}=$ Angwan Waje; $\mathrm{D}=$ Angan Nepa $\mathrm{E}=$ Area Command; $\mathrm{F}=$ Convocation Square; $\mathrm{G}$ = CRDP; $\mathrm{H}=$ Sohon Kasuwa $\mathrm{I}=$ High Court; $\mathrm{J}=$ Locust

Table 3. Antibiotic resistance pattern of bacterial isolates from Kunun-zaki drinks sold

\begin{tabular}{|c|c|c|c|c|c|}
\hline \multirow[b]{2}{*}{ Antibiotics } & \multicolumn{5}{|c|}{ Percentage of resistance of isolates } \\
\hline & Concentration $(\mu \mathrm{g})$ & Escherichia coli & Enterobacter aerogenes & Streptococcus spp & Staphylococcus aureus \\
\hline Septrin & 30 & 68.7 & 14.3 & 0.0 & 16.7 \\
\hline Chloramphenicol & 30 & 75.0 & 21.4 & 0.0 & 0.0 \\
\hline Sparfloxacin & 5 & 68.7 & 35.7 & 33.3 & 16.7 \\
\hline Ciprofloxacin & 5 & 50.0 & 7.1 & 33.3 & 16.7 \\
\hline Amoxicillin & 30 & 12.0 & 35.7 & 0.0 & 0.0 \\
\hline Augmentin & 30 & 25.0 & 50.0 & 33.3 & 0.0 \\
\hline Gentamicin & 10 & 12.0 & 14.3 & 0.0 & 33.4 \\
\hline Pefloxacin & 10 & 0.0 & 42.9 & 0.0 & 33.4 \\
\hline Tarivid & 30 & 31.3 & 28.8 & 38.3 & 0.0 \\
\hline Streptomycin & 10 & 31.3 & 14.3 & 33.3 & 16.7 \\
\hline
\end{tabular}

Table 2 shows the bacterial species isolated from samples of Kunun-zaki drinks sold at the different locations in Keffi. The isolates were Escherichia coli, Staphylococcus aureus, Streptococcus spp. and Enterobacter aerogenes. Escherichia coli was the most predominant isolate with very high percentage occurrence $(100 \%)$, followed by Enterobacter aerogenes (70\%) and Staphylococcus aureus had the least occurrence $(30 \%)$.

Table 3 shows the Antibiotic resistance pattern of the bacterial species isolated from Kunun-zaki drinks sold in Keffi metropolis. E. coli exhibited very high percentage resistance to chloramphenicol $(75.0 \%)$ followed by Septrin (68.7\%) and Sparfloxacin (68.7\%) respectively, whereas there was no resistance to Perfloxacin $(0.0 \%)$. The highest percentage resistance for Enterobacter aerogenes was recorded with Augmentin (50.0\%) and the least resistance was recorded with Ciprofloxacin (7.1\%). The percentage resistance Streptococcus spp. isolated was relatively low which ranged from $38.3 \%$ to $33.3 \%$ for the antibiotics to which this species showed resistance (Trivid, Sparfloxacin, Ciprofloxacin, Augmentin and Streptomycin). However, the isolates of the Streptococcus spp. showed completely no resistance $(0.0 \%)$ to Septrin, Chloramphenicol, Amoxicillin, Gentamicin and Perfloxacin. Similarly, the percentage resistance of Staphylococcus aureus isolated was relatively low which ranged from $33.4 \%$ to $16.7 \%$ for the antibiotics to which these isolates showed resistance (Gentamicin, Perfloxacin, Septrin, Sparfloxacin, Ciprofloxacin and Streptomycin).

\section{DISCUSSION}

The relative microbial counts recorded were indicative of high level of microbial contamination. Kunun-zaki sold at Sohon Kasuwa had the highest counts of $9.1 \times 10^{8} \mathrm{cfu} / \mathrm{mL}$, while the High Court location had the lowest counts of $3.6 \times 10^{8} \mathrm{cfu} / \mathrm{mL}$. However, there was no significant difference $(p>0.05)$ in the microbial counts of the Kunun-zaki sold at the different locations of the metropolis which is indicative that the beverage sold at the different locations most likely had similar microbial quality. This may be due to the fact that similar handling procedures are employed during processing and marketing of the beverage. The high microbial counts may to a large extent be attributed to lack of effective precautions on hygiene practice in handling procedures during processing of the beverage. The practice of addition of some quantity of water to Kunun-zaki after fermentation may also be a source of introducing microbial contaminants which may have come from the water itself or from the utensils used for such purposes. Amusa and Ashaye (2009) had earlier 
reported that the presence of coliforms such as Esherichia coli in hawked Kunun-zaki was as a result of contaminated water, containers, as well as dirty environment where the Kunun-zaki were being processed and hawked.

The percentage occurrence of Escherichia coli, Staphylococcus aureus, Streptococcus spp and Enterobacter aerogenes in the the samples analyzed is a pointer to the fact that the Kunun-zaki drink sold in the different locations in Keffi is contaminated with potentially pathogenic bacteria and this may have come from the water used for domestic purposes, or the human handlers during processing and sales of the product, respectively. This is in agreement with Amusa and Ashaye (2009) and Akoma et al. (2013), who had reported that water used for production coupled with the crude method of production and packaging under improper sanitary conditions predisposes Kunun-zaki drink to microbial contamination by an array of both gram negative and gram positive bacteria. There is therefore need for surveillance by Public Health officials to ensure safety of the Kunun-zaki being sold in Keffi for public consumption. There is need to also ensure that the water used for production especially post-heating processing of the Kunun-zaki is safe and free from microbial contaminants. The source of contamination may also have come from the spices used additives (Essien et al., 2009; Lawal, 2012).

Antibiogram of the isolates revealed varying levels of resistance to the antibiotics tested. Escherichia coli showed high resistance to chloramphenicol (75\%), followed by Septrin (68.7\%) and Spafloxacin (68.7\%), while Enterobacter aerogenes, Streptococcus spp and Staphylococcus aureus had low rates of resistance to all the antibiotics tested. However, E. coli had very high sensitivity to Pefloxacin (100\%), followed by Gentamicin (88\%), Augmentin (75\%), tarivid (68.7\%) and Streptomycin (68.7\%). Streptococcus spp were the most susceptible isolates which had very high sensitivity $(100 \%)$ to five of the antibiotics tested, namely, Septrin, Chloramphenicol, Amoxicillin, Gentamicin and Perfloxacin, respectively. Staphylococcus aureus was also very sensitive $(100 \%)$ to Chloramphenicol, Amoxicillin, Augmentin and Tarivid, respectively.

The sensitivity of these isolates to the antibiotics used are comparable to earlier reports (Inyang, 2009; Udo et al., 2009; Tagoe et al., 2011; Ibiene et al., 2011).

The prevalence of resistant strains of E. coli, Enterobacter aerogenes, Streptococcus spp and Staphylococcus aureus in Kunun-zaki is a reflection of the use and misuse of the antibiotics in the society. This is not surprising because outside the hospital environment, the general populace have access to various kinds of antibiotics at any drug store even without any prescription from a medical practitioner.

The Public Health implication of this study is that antimicrobial resistant strains of pathogenic bacteria may colonize the human population through consumption of contaminated Kunun-zaki and this would lead to chemotherapeutic failures among the human consumers of this popular beverage in the Keffi metropolis.

\section{CONCLUSION}

The presence of resistant strains of E. coli, Enterobacter aerogenes, Staphylococcus aureus and Streptococcus spp in Kunun-zaki sold in Keffi suggests that consumption of this beverage has potential health hazard to the consumers in Keffi, Nasarawa state, Nigeria. The consumers of this popular drink were therefore placed at health risk which may culminate into failures of commonly used clinical antibiotics for the treatment of infections.

\section{ACKNOWLEDGEMENT}

The reasearchers are grateful to the Microbiology Unit, Department of Biological Sciences, Nasarawa State University, Keffi, Nigeria, for providing us with the laboratory materials and facilities used in this investigation.

\section{REFERENCES}

Adebayo, G.B., G.A. Otunola and T.A. Ajao, 2010. Physiochemical, microbiological and sensory characteristics of Kunu prepared from millet, maize and guinea corn and stored at selected temperatures. Adv. J. Food Sci. Techn., 2: 41-46.

Adedokun, I.I., S.U.Okorie, B.C. Nwokeke and E.N. Onyeneke, 2012. Effect of Aframomum danelli ans black pepper crude extracts on physio-chemical and sensory properties of Kunun-zaki during storage. J. Food Techn., 10: 97-102.

Akoma, O., O.O. Agarry and I. Nkama, 2012. The microbiological quality of freeze-dried Kunun-zaki during production and storage. Intl. J. Biol. Pharm., 1: 1397-1410.

Akoma, O., O.O. Agarry and I. Nkama, 2013. A study on the production and consumption pattern of Kunun-zaki: A cereal based ethnic fermented beverage of Northern Nigeria. Br. J. Appl. Sci. Techn., 3: 1220-1227. 
Amusa, N.A. and O.A. Ashaye, 2009. Microbiological and nutritional quality of hawked Kunun (a sorghum based non-alcoholic beverage) widely consumed in Nigeria. Pak J. Nutr., 8: 20-25.

Bukar, A., A. Uba and T.I. Oyeyi, 2010. Occurrence of some entropathogenic bacteria in some minimally and fully processed ready-to-eat foods in Kano metropolis, Nigeria. Afr. J. Food Sci., 4: 32-36.

Cheesbrough, M., 2006. District Laboratory Practice in Tropical Countries, Part 2. 1st Edn., Cambridge University Press, Cambridge, ISBN-10: 113944929X, pp: 440.

CLSI, 2009. Performance Standards for Antimicrobial Susceptibility Testing: Nineteenth Informational Supplement. Clinical and Laboratory Standards Institute, Wayne, pp: 149.

Essien, E., C. Monago, E.A. Edor, 2009. Evaluation of the nutritional and microbiological quality of kunun (a cereal based non-alcoholic beverage) in rivers State, Nigeria. Int. J. Nutr. Wellness.

Folasade, M. and O. Oyenike, 2012. Effect of sesame seed addition on the chemical and sensory qualities of sorghum based Kunun-zaki drink. Afr. J. Food Sci. Techn., 3: 204-212.

Holt, J.H., 1994. Bergey's Manual of Determinative Bacteriology. 1st Edn., Lippincott Williams and Wilkins, Baltimore, ISBN-10: 0683006037, pp: 787.

Ibiene, A.A., I.O. Okonko and E.V. Agbeyi, 2011. Multidrug Resistant (MDR) bacteria isolated from different drinking water sources. New York Sci. J., 4: $50-56$.

Inyang, C.U., 2009. Antibiogram of bacteria isolated from borehole water. Nig. J. Microbiol., 23: 1810-1816.

Lawal, O.A., 2012. Microbial quality of Kunun-zaki beverage sold in Ile-Ife, Osun State. J. Food Techn., 10: 4-7.
Maji, A.A., J. Omale and O.E. Chigozie, 2011. Effect of chemical treatment and pasteurization on the shelf life of Kunun zaki (sorghum and maize gruel). Eur. J. Food Res. Rev., 1: 61-70.

Oluwajoba, S.O., F.A. Akinyosoye and O.V. Oyetayo, 2013. Comparative sensory and proximate evaluation of spontaneously fermenting kunu-zaki made from germinated and ungerminated composite cereal grains. Food Sci. Nutr., 1: 336-349. DOI: $10.1002 /$ fsn 3.45

Oluwalana, I.B. and T.O. Adedeji, 2013. Nutritional composition of a non-alcoholic beverage spiced with Zingiber officinale extract produced from Sorghum bicolor stem sheath. Int. J. Food Sci. Nutr. Eng., 3: 21-27. DOI: 10.5923/j.food.20130303.01

Sanders, E.R., 2012. Aseptic laboratory techniques: Plating methods. J. Vis. Ex., 63: e3064-e3064. PMID: 22617405

SPSS, 2012. Statistical Package for Social Sciences for Windows.

Tagoe, D.N.A., S.A. Nyako, S.A. Arthur and E. Birikorang, 2011. A study of antibiotic susceptibility pattern of bacteria isolates in sachet drinking water sold in cape coast metropolis of Ghana. Res. J. Microbiol., 6: 153-158. DOI: 10.3923/jm.2011.153.158

Udo, S., I. Andy, A. Umo and M. Ekpo, 2009. Potential human pathogens (bacteria) and their antibiogram in ready-to-eat salads sold in calabar, South-South, Nigeria. Int. J. Trop. Med., 5: 1-1.

Wikipedia, 2013. The Geographical Location of Keffi.

Willey, J.M., Sherwood, L.M. and C.J. Woolverton, 2008. Prescott, Harley and Klein's Microbiology. 7th Edn., McGraw-Hill Higher Education, Boston, ISBN-10: 0071102310, pp: 1088. 